\title{
PENGARUH SIKAP DAN NORMA SUBYEKTIF TERHADAP MINAT MAHASISWI UNIVERSITAS TADULAKO MEMBELI LIPSTIK MEREK LA TULIPE
}

\author{
DITA AMALIAH \\ WAHYUNINGSIH \\ SYAMSUL BAHRI DG. PARANI \\ Program Studi S1 Manajemen, Fakultas Ekonomi, Universitas Tadulako \\ Email :amaliahdita@gmail.com
}

\begin{abstract}
The purpose of this study is to learn and increase student's interest in Tadulako University on purchasing brand lipstick La Tulipe. The variables of this research are attitude $\left(X_{1}\right)$ and subjective norm $\left(X_{2}\right)$, and the dependent variable is interest $(Y)$. The research method used in this study is descriptive causal method with 61 sample and purposive sampling technique and method of analysis, Multiple Linear Regression with the help of computer program SPSS for windows, Release 16.0. The results showed that : 1). Subjective Attitudes and Norms Simultaneously Significantly Affects Student Interest The University of Tadulako buys La Tulipe brand lipstick; 2). Attitudes partially significant effect on Student Interest TadulakoUniversity bought brand lipstick La Tulipe; 3). Subjective Norms partially significant effect on Student Interest University Tadulako buy brand lipstick La Tulipe.
\end{abstract}

Keyword: Attitude, Subjective Norms, Interests

\begin{abstract}
Abstrak
Tujuan penelitian ini adalah untuk mengetahui dan menganalisis pengaruh sikap dan norma subyektif secara serempakdan parsial terhadap minat Mahasiswi Universitas Tadulako membeli lipstick merek La Tulipe. Variabel penelitian ini yaitu sikap $\left(\mathrm{X}_{1}\right)$ dan norma subyektif $\left(\mathrm{X}_{2}\right)$. Sedangkan variabel dependen yaitu minat $(\mathrm{Y})$. Metode penelitian yang digunakan adalah metode deskriptif kausal dengan jumlah sampel 61 orang dengan teknik purposive sampling dan Metode analisis, Regresi Linear Berganda dengan bantuan program komputer SPSS for windows, Release 16.0. Hasil penelitian menunjukan bahwa: 1). Sikap dan Norma Subyektif secaraserempak berpengaruh signifikan terhadap Minat Mahasiswi Universitas Tadulako membeli lipstick merek La Tulipe; 2). Sikap secara parsial berpengaruh signifikanterhadap Minat Mahasiswi Universitas Tadulako membeli lipstick merek La Tulipe; 3). Norma Subyektif secara parsial berpengaruh signifikanterhadap Minat Mahasiswi Universitas Tadulako membeli lipstick merek La Tulipe.
\end{abstract}

Kata Kunci: Sikap, Norma Subyektif, Minat

\section{PENDAHULUAN}

Indonesia sebagai negara berkembang dilihat sebagai pasar potensial yang memiliki pertumbuhan. Kondisi ini sangat dimanfaatkan oleh produsen kosmetik. Jumlah penduduk di Indonesia sekitar 261,1 juta jiwa dan sifat konsumen Indonesia yang konsumtif, menjadikan Indonesia pasar yang menjanjikan bagi perusahaan kosmetik. Saat ini perkembangan industri kosmetik Indonesia tergolong solid (Dunia Industri Kosmetik).

Salah satu jenis industri yang termasuk sektor industri kosmetik adalah industri lipstik, industri ini sangat penting karena hampir semua wanita memakai lipstik. Pada umumnya lipstik selalu hadir dalam tas wanita selain bedak wajah, maka hal tersebut merupakan potensi bagi industri lipstik dalam meningkatkan jumlah penjualannya di pasaran. Lipstikmerek La Tulipe merupakan salah satu merek lipstik buatan lokal yang sudah lama terkenal di Indonesia. Bagi para pencinta lipstik tentunya tidak asing dengan lipstikmerek La Tulipe, karena lipstik merek ini pertama kali diluncurkan pada tahun 1980 dan hampir seluruh wanita Indonesia menjadi penggunanya (www.latulipe-id.com).

Peminat lipstik yang dulunya hanya diminati oleh wanita dewasa saja kini mulai berkembang di kalangan remaja. Salah satu peminat lipstik dikalangan remaja ialah Mahasiswi di Universitas Tadulako. Berdasarkan fenomena yang terjadi saat ini, dari hasil wawancara pada beberapa Mahasiswi Universitas Tadulako yang telah menggunakan lipstik merek La Tulipe, mengatakan bahwa minat 
Amaliah, D.

mereka memilih untuk membeli atau menggunakan lipstik merek La Tulipe sebagian besar dipengaruhi oleh dua hal, yaitu sikap dan norma subyektif.

Adapun tujuan yang ingin dicapai dalam penelitian ini adalah:

1. Untuk mengetahui pengaruh serempak dan signifikan sikap dan norma subyektif terhadap minat Mahasiswi Universitas Tadulako membeli lipstik merek LaTulipe.

2. Untuk mengetahui pengaruh signifikan sikap terhadap minat Mahasiswi Universitas Tadulako membeli lipstik merek La Tulipe.

3. Untuk mengetahui pengaruh signifikan norma subyektif terhadap minat Mahasiswi Universitas Tadulako membeli lipstik merek La Tulipe.

\section{KAJIAN LITERATUR DAN PENGEMBANGAN HIPOTESIS}

\section{Sikap}

Menurut Kotler dan Armstrong (2008) sikap adalah Evaluasi, perasaan, dan kecenderungan dari individu terhadap suatu obyek yang relatif konsisten. Sikap menempatkan orang dalam kerangka pemikiran mengenai menyukai atau tidak menyukai sesuatu, mengenai mendekati atau menjauhi. Beberapa komponen sikap yang menjadi dasar dalam menciptakan atribut produk (Ferrinadewi 2008):

1. Komponen Kognitif

komponen kognitif terdiri dari keyakinan dan pengetahuan konsumen tentang produk.

2. Komponen Afektif

Komponen afektif merupakan perasaan atau emosi kita terhadap obyek tertentu. Biasanya diungkapkan dalam bentuk rasa suka atau rasa tidak suka.

3. Komponen Konatif

Keyakinan dan rasa suka pada suatu produk akan mendorong konsumen melakukan tindakan sebagai wujud dari keyakinan dan perasaannya.

\section{Norma Subyektif}

Dewi dan Ardani (2016) menyimpulkan bahwa norma subyektif merupakan keyakinan individu mengenai harapan orang-orang sekitar yang berpengaruh (significant other) baik perorangan ataupun perkelompok untuk menampilkan perilaku tertentu atau tidak. Norma subyektif terbentuk dari komponen keyakinan normatif dan motivasi seseorang, artinya individu dapat terpengaruh dan dapat pula tidak berpengaruh oleh pandangan orang lain.

Norma subyektif ditentukan oleh adanya keyakinan normatif (normative beliefs) dan keinginan untuk mengikuti (motivation to comply), Anggelina (2014). Keyakinan normatif (normative beliefs) adalah keyakinan tentang harapan normatif orang lain yang memotivasi seseorang untuk memenuhi harapan tersebut). Keyakinan normatif merupakan indikator yang kemudian menghasilkan norma subjektif (subjective norms), sedangkan keinginan untuk mengikuti (motivation to comply) merupakan keinginan individu mematuhi pandangan orang lain yang berpengaruh dalam hidupnya.

\section{Minat}

Kotler \& Keller (2009) menjelaskan minat atau niat adalah kecenderungan untuk melakukan tindakan/perilaku atau sesuatu yang segera mendahului tingkah laku pembelian yang sebenarnya. Tingkah laku konsumen adalah sebagai segala sesuatu yang dilakukan oleh seseorang yang berhubungan dengan memperoleh, menentukan pilihan, atau menggunakan produk atau jasa. Tingkah laku ini dapat berupa tingkah laku yang tampak (overt behavior) atau tingkah laku yang tidak tampak (covert behavior). Minat beli timbul karena adanya ketertarikan dari individu tersebut terhadap produk yang diamati dan diiringi dengan kemampuan untuk membeli produk tersebut. 


\section{KerangkaPemikiran}

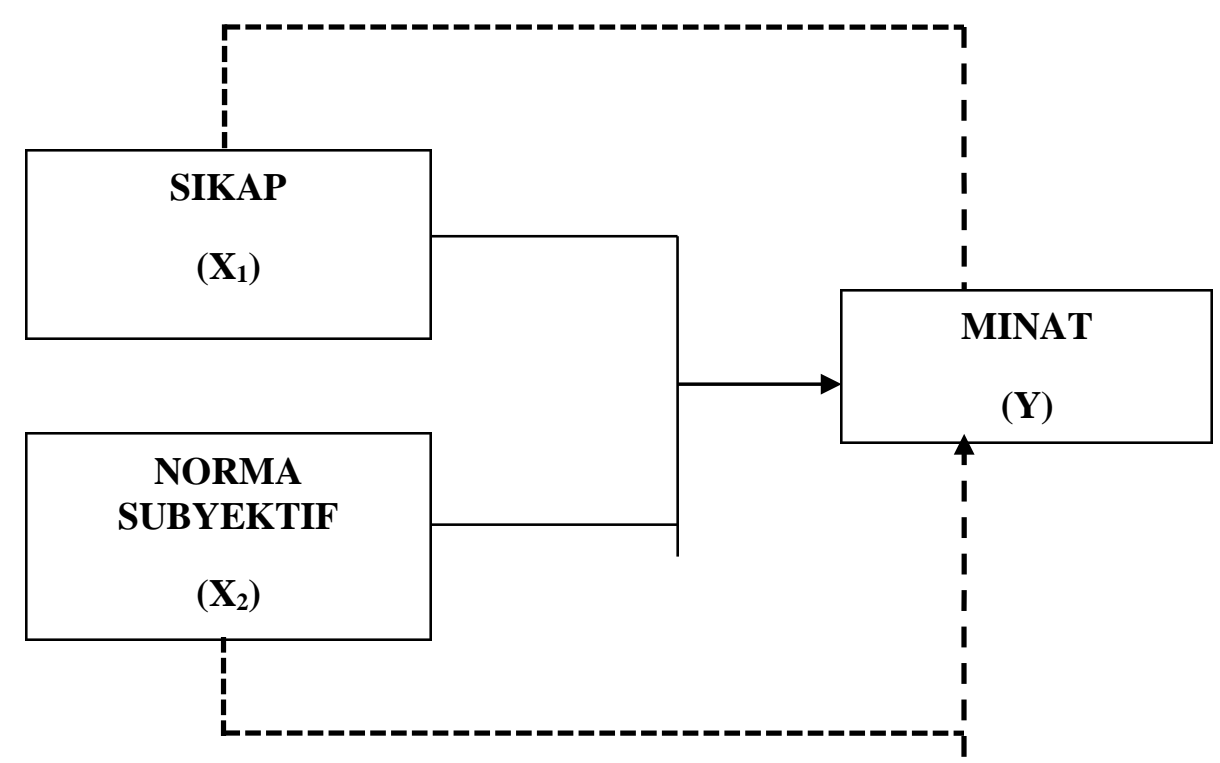

Gambar.1 Kerangka Pemikiran

\section{Hipotesis}

Berdasarkan latar belakang dan kerangka pemikiran diatas, dugaan sementara yang diajukan oleh peneliti dalam penelitian ini atas masalah yang telah dirumuskan adalah sebagai berikut:

1. Sikap dan norma subyektif secara serempak berpengaruh positif dan signifikan terhadap minat Mahasiswi Universitas Tadulako membeli lipstik merek La Tulipe.

2. Sikap secara parsial berpengaruh positif dan signifikan terhadap minat Mahasiswi Universitas Tadulako membeli lipstik merek La Tulipe.

3. Norma subyektif secara parsial berpengaruh positif dan signifikan terhadap minat Mahasiswi Universitas Tadulako membeli lipstik merek La Tulipe.

\section{METODE PENELITIAN}

Jenis penilitian ini adalah penelitian deskriptif dan kausal, Menurut Sugiono (2014) penelitian deskriptif adalah penelitian untuk menganalisa data dengan cara mendeskripsikan atau menggambarkan data yang telah terkumpul sebagaimana adanya tanpa bermaksud membuat kesimpulan yang berlaku untuk umum atau generalisasi. Sedangkan studi kausalitas menurut Sugiono (2014) adalah penelitian yang menunjukan arah hubungan antara variabel bebas dengan variabel terikat, disamping mengukur kekuatan hubungannya. Studi kausalitas mempertanyakan masalah sebab-akibat.

Menurut Sugiyono (2014) objek penelitian adalah sesuatu yang dituju peneliti dari sebuah maksud diadakannya riset penelitian untuk ditemukan pembuktian secara ilmiah. Berdasarkan pada pemahaman tersebut, maka dalam konteks penelitian ini yang dimaksud dengan objek penelitian ini adalah sikap dan norma subyektif sebagai variabel yang mempengaruhi (Independen) sedangkan variabel yang dipengaruhi (Dependen) ialah minat Mahasiswi Universitas Tadulako membeli lipstik merek La Tulipe. Subjek penelitian ini adalah Mahasiswi Universitas Tadulako yang berminat membeli lipstik merek La Tulipe. Penilitian ini dilakukan di Universitas Tadulako. Peneliti membutuhkan waktu selama 1 bulan untuk melakukan penelitian.

Populasi dalam penelitian ini adalah Mahasiswi Universitas Tadulako yang berminat membeli lipstik merek La Tulipe . Populasi dalam penelitian adalah tidak terbatas. Metode pengambilan sampel yang digunakan dalam penelitian ini adalah non-probability sampling dan menggunakan teknik purposive 
Amaliah, D.

sampling yaitu teknik yang digunakan dalam pengambilan sampel berdasarkan dengan kriteria yang telah ditentukan.

Jumlah sampel yang akan diambil untuk mewakili populasi dalam penelitian ini sebanyak 61 sampel. peneliti merujuk pada teori Roscoe, Sugiyono (2015) bila dalam penelitian akan melakukan analisis dengan multivariate (korelasi atau regresi berganda misalnya), maka jumlah anggota sampel minimal 10 kali dari jumlah variabel yang diteliti (independen + dependen). Jumlah variabel dalam penelitian ini adalah 2 variabel independen yaitu variabel sikap dan variabel norma subyektif serta 1 variabel dependen yaitu minat. Adapun sampel dalam penelitian ini menggunakan kriteria sebagai berikut:

1. Mahasiswi Universitas Tadulako

2. Bersedia mengisi kuesioner yang diberikan

3. Belum pernah menggunakan lipstick merek La Tulipe

4. Berminat untuk membeli lipstick merek La Tulipe

\section{Analisis Kuantitatif}

1. Uji Asumsi Dasar

a. Uji Normalitas

Uji Normallitas digunakan untuk menguji apakah dalam sebuah model regresi variabel (pengganggu) dependen dan independen atau keduanya memiliki distribusi normal, Ghozali (2013). Model regresi yang baik adalah distribusi data normal atau mendekati normal. Deteksi normalitas dilakukan dengan melihat penyebaran data (titik) pada sumbu diagonal dan grafik. Dasar pengambilan keputusan:

1. Jika data yang menyebar di sekitar garis diagonal dan mengikuti arah garis diagonal, maka model regresi memenuhi asumsi normalitas.

2. Jika data menyebar jauh dari garis diagonal dan tidak mengikuti arah garis diagonal, maka model regresi tidak memenuhi asumsi normalitas.

2. Uji Penyimpangan Asumsi Klasik

a. Uji Multikolinieritas

Uji Multikolinieritas digunakan untuk menguji apakah model regresi ditemukan adanya kolerasi antara variabel bebas independen. Model regresi yang baik seharusnya antara variabel independen tidak terjadi korelasi antara variabel independen, Ghozali (2013). Uji multikolinieritas dapat dilakukan dengan dua cara yaitu dengan melihat:

1. Nilai tolerance dan lawanya.

2. VIF (Varlance Inflation Faktors) Jika tolerance $\leq 0.10$ atau sama dengan nilai VIF $\geq 10$ maka menunjukan adanya multikolinieritas, dan sebaliknya, Ghozali (2013).

b. Uji Heteroskedastisitas

Menurut (Ghozali 2013) uji heteroskedastisitas yaitu untuk menguji apakah dalam model regresi terjadi ketidaksamaan variance dari residual satu pengamatan ke pengamatan yang lain. Jika variance dari residual satu pengamatan ke pengamatan lain tetap, maka disebut homoskedastisitas dan jika berbeda disebut heteroskedastisitas Model regresi yang baik adalah tidak terjadi heteroskedastisitas. Untuk mendeteksi adanya heteroskedastisitas dilakukan dengan melihat ada tidaknya pola tertentu dari grafik, dimana sumbu $\mathrm{X}$ dan $\mathrm{Y}$ telah diprediksi, dan sumbu $\mathrm{X}$ adalah residual ( $\mathrm{Y}$ prediksi $-\mathrm{Y}$ sesungguhnya) yang telah di-studentized.

Dasar pengambilan keputusan:

1. Jika ada pola tertentu, seperti titik-titik (poin-poin) yang ada membentuk suatu pola tertentu yang teratur (bergelombang, melebar, kemudian menyempit) maka telah terjadi heteroskedastisitas.

2. Jika tidak ada pola yang jelas, serta titik-titik menyebar diatas dan dibawah angka nol pada sumbu Y, maka tidak terjadi heteroskedastisitas.

3. Analisis Regresi Linier Berganda

Penelitian ini menggunakan analisis regresi linear berganda dengan tujuan untuk menguji pengaruh sikap dan norma subyektif terhadap minat Mahasiswi Universitas Tadulako membeli lipstik merek $L a$ Tulipe. Untuk menguji pengaruh variabel sikap dan norma subyektif terhadap minat Mahasiswi Universitas Tadulako membeli lipstik merek La Tulipe maka dapat dirumuskan sebagai berikut: 


$$
\mathbf{Y}=\mathbf{a}+
$$

Keterangan:

$$
\begin{array}{ll}
\mathrm{a} & =\text { Konstanta } \\
\mathrm{Y} & =\text { Variabel Dependen } \\
\mathrm{b}_{1}, \mathrm{~b}_{2}, \mathrm{~b}_{3} & =\text { Koefisien Regresi masing-masing Variabel } \\
\mathrm{X}_{1}-\mathrm{X}_{\mathrm{n}} & =\text { Variabel Independen } \\
\mathrm{e} & =\text { Term Error (Tingkat Kesalahan) }
\end{array}
$$

Apabila ditransformasikan dalam penelitian ini, maka persamaan regresi linear berganda dapat dirumuskan kembali sebagai berikut:

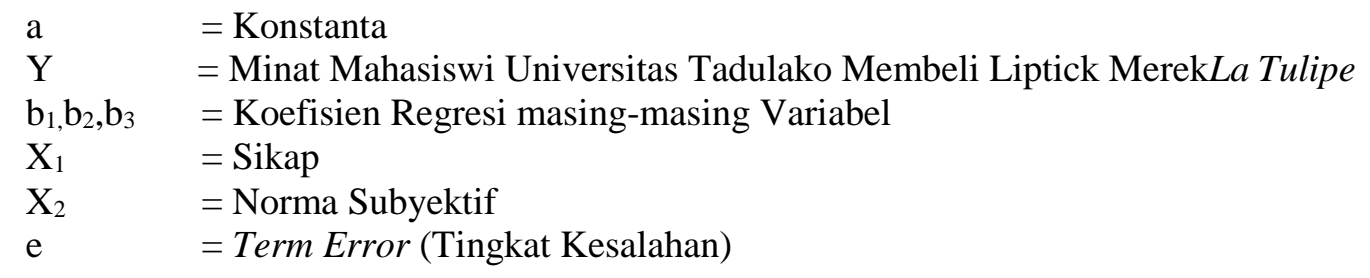

\section{HASIL DAN PEMBAHASAN}

\section{Hasil Uji Validitas dan Reliabilitas}

Uji validitas adalah sejauh mana kehandalan sebuah alat ukur dalam mengukur apa yang diukur dan uji reliabilitas adalah alat untuk mengukur suatu kuisioner yang merupakan indikator dari variabel dan konstruk Ghozali (2013). Berikut ini adalah hasil uji validitas dan reliabilitas atas item pertanyaan yang terdapat dalam kuesioner penelitian terhadap variabel Sikap (X1), Norma Subyektif (X2), dan Minat (Y). Adapun hasilnya disajikan dalam tabel 1 berikut:

Tabel.1

Hasil Uji Validitas dan Reabilitas

\begin{tabular}{|l|l|l|l|l|l|}
\hline Variabel & Item & $\begin{array}{l}\text { Total } \\
\text { Correlation }\end{array}$ & Ket & $\begin{array}{l}\text { Cronbach } \\
\text { Alpha }\end{array}$ & Ket \\
\hline Sikap (X1) & X1.1 & 0.334 & Valid & & \\
& X1.2 & 0.518 & Valid & & \\
& X1.3 & 0.718 & Valid & & Reliabel \\
& X1.4 & 0.667 & Valid & 0.844 & \\
& X1.5 & 0.420 & Valid & & \\
& X1.6 & 0.587 & Valid & & \\
& X1.7 & 0.719 & & & \\
& X1.8 & 0.667 & Reliabel \\
\hline Norma Subyektif (X2) & X2.1 & 0.728 & Valid & & \\
& X2.2 & 0.886 & Valid & & \\
& X2.3 & 0.812 & Valid & & \\
& X2.4 & 0.791 & Valid & & \\
& X2.5 & 0.821 & Valid & 0.948 & \\
& X2.6 & 0.885 & Valid & & \\
& X2.7 & 0.853 & Valid & & \\
& X2.8 & 0.807 & Valid & & \\
& & & & & \\
\hline Minat (Y) & Y1 & 0.725 & Valid & & \\
& Y2 & 0.756 & Valid & 0.808 & \\
& Y3 & 0.512 & Valid & & \\
& & & & & \\
\end{tabular}

Berdasarkan hasil uji validitas dan reliabilitas diperoleh bahwa seluruh variabel memiliki koefisien Cronbach Alpha (a) lebih besar dari 0,60 sehingga berdasarkan syarat minimum reliabilitas lebih besar 
dari 0,60 maka seluruh variabel yang digunakan reliabel dan dapat digunakan dalam penelitian.

Sedangkan uji validitas terhadap seluruh variabel juga menunjukan nilai koefisien korelasi yang lebih besar dari 0,30 sehingga item pernyataan yang ada valid untuk digunakan.

\section{Hasil Uji Analisis Regresi Linear Berganda}

Penelitian ini menggunakan analisis regresi linear berganda dengan tujuan untuk menguji pengaruh sikap dan norma subyektif terhadap minat. Untuk lebih jelasnya hasil analisis regresi linear berganda dapat dilihat pada tabel 2 berikut:

Tabel 2

Hasil Uji Analisis Regresi Linear Berganda

\begin{tabular}{|c|c|c|c|c|c|c|}
\hline \multicolumn{7}{|c|}{ Dependen Variabel Y = Minat } \\
\hline \multirow{2}{*}{\multicolumn{2}{|c|}{$\begin{array}{c}\text { Variabel } \\
\text { Independen }\end{array}$}} & \multicolumn{2}{|c|}{$\begin{array}{c}\text { Unstandardized } \\
\text { Coefficients }\end{array}$} & \multirow{2}{*}{$\begin{array}{c}\text { Standardized } \\
\text { Coefficients }\end{array}$} & \multirow[t]{2}{*}{$\mathbf{t}$} & \multirow[t]{2}{*}{ Sig. } \\
\hline & & B & Std. Error & & & \\
\hline \multirow{3}{*}{1} & (Constant) & 1.354 & .509 & & 2.661 & .010 \\
\hline & X1 (Sikap) & .310 & .148 & .218 & 2.093 & .041 \\
\hline & $\begin{array}{c}\text { X2 (Norma } \\
\text { Subyektif) }\end{array}$ & .539 & .077 & .730 & 7.000 & .000 \\
\hline \multirow{2}{*}{\multicolumn{2}{|c|}{$\begin{array}{l}\text { Multiple R } \\
\text { Adjusted R Square }\end{array}$}} & \multicolumn{5}{|c|}{$=0.678$ Sig. $F=0.000$} \\
\hline & & $=0.44$ & & inokat kenero & an $95 \%$ & \\
\hline
\end{tabular}

Berdasarkan tabel 2 di atas, dapat di tulis dalam bentuk persamaan regresi linear berganda. Untuk lebih jelasnya bentuk persamaan tersebut dapat dilihat sebagai berikut:

$$
\mathrm{Y}=1.354+0.310 \mathrm{X}_{1}+0.539 \mathrm{X}_{2}+\mathrm{e}
$$

Berdasarkan penjabaran di atas menunjukkan bahwa, variabel independen yang dianalisis yaitu variabel $\left(\mathrm{X}_{1}\right.$, dan $\mathrm{X}_{2}$, ) memberikan pengaruh positif terhadap variabel dependen $(\mathrm{Y})$, yaitu minat Mahasiswi Universitas Tadulako membeli lipstik merek La Tulipe. Untuk lebih jelasnya penjelasan bentuk persamaan tersebut dapat dilihat berikut ini:

1. Nilai Konstanta sebesar 1.354, artinya jika variabel (sikap dan norma subyektif) bernilai 0 , maka variabel dependen (minat Mahasiswi Universitas Tadulako membeli lipstik merek La Tulipe) nilainya sebesar1.354.

2. Koefisien regresi sikap $\left(\mathrm{X}_{1}\right)$ sebesar0.310, artinya jika sikap naik satu satuan, maka minat Mahasiswi Universitas Tadulako membeli lipstik merek La Tulip enaik sebesar0.310.

3. Koefisien regresi norma subyektif $\left(\mathrm{X}_{2}\right)$ 0.539, artinya jika norma subyektif naik satu satuan, maka minat Mahasiswi Universitas Tadulako membeli lipstik merek La Tulipe naik sebesar 0.539 .

\section{Hasil Uji Hipotesis \\ Hasil Pengujian Hipotesis Secara Simultan (Uji F)}

Berdasarkan hipotesis pertama $\left(\mathrm{H}_{1}\right)$ adalah untuk mengetahui apakah sikap dan norma subyektif secara serempak berpengaruh signifikan terhadap minat Mahasiswi Universitas Tadulako membeli lipstik merek La Tulipe. Untuk lebih jelasnya hasil dapat dilihat pada tabel 3 berikut: 
Tabel. 3

Hasil Uji F (Serempak)

ANOVA $^{b}$

\begin{tabular}{|rr|r|r|r|r|r|}
\hline \multicolumn{2}{|l|}{ Model } & Sum of Squares & Df & Mean Square & F & Sig. \\
\hline $1 \quad$ Regression & 7.545 & 2 & 3.773 & 24.689 & $.000^{2}$ \\
& Residual & 8.863 & 58 & .153 & & \\
Total & 16.408 & 60 & & & \\
\hline
\end{tabular}

Berdasarkan Tabel 3 di atas diperoleh Sig.F yaitu 0.000, artinya nilai tersebut lebih kecil dibandingkan dengan nilai yang disyaratkan yaitu $\alpha=0.05$ dengan tingkat kepercayaan $95 \%$. dengan demikian dapat dinyatakan bahwa variabel sikap dan norma subyektif secara serempak berpengaruh signifikan terhadap minat Mahasiswi Universitas Tadulako membeli lipstik merek La Tulipe.

\section{Hasil Pengujian Hipotesis Secara parsial (Uji t)}

Hasil Uji t adalah untuk mengetahui apakah variabel $\left(\mathrm{X}_{1}\right.$ dan $\left.\mathrm{X}_{2}\right)$ secara parsial berpengaruh terhadap Y. Untuk lebih jelasnya hasil dapat dilihat pada tabel 4 berikut:

Tabel. 4

\section{Hasil Uji t (Parsial)}

\begin{tabular}{|c|c|c|c|}
\hline \multicolumn{2}{|c|}{ Variabel } & t & Sig \\
\hline \multirow{3}{*}{1} & $($ Constant $)$ & 2.661 & .010 \\
\cline { 2 - 4 } & $\mathrm{X}_{1}$ & 2.093 & .041 \\
\cline { 2 - 4 } & $\mathrm{X}_{2}$ & 7.000 & .000 \\
\hline
\end{tabular}

Berdasarkan tabel 4 di atas hasil uji t pengujian variabel $\left(\mathrm{X}_{1}\right.$ dan $\left.\mathrm{X}_{2}\right)$ terhadap $\mathrm{Y}$ dijelaskan sebagai berikut:

1. Hasil Pengujian Hipotesis $X_{1}$ terhadap $Y$

Hipotesis kedua $\left(\mathrm{H}_{2}\right)$ adalah untuk mengetahui apakah sikap $\left(\mathrm{X}_{1}\right)$ secara parsial berpengaruh signifikan terhadap minat Mahasiswi Universitas Tadulako membeli lipstick merek La Tulipe. Berdasarkan tabel di atas menunjukkan bahwa sikap $\left(\mathrm{X}_{1}\right)$ memiliki nilai signifikan sebesar 0.04 . Artinya nilai tersebut $<$ dari taraf yang disyaratkan yaitu $\alpha=0.05$, maka dapat disimpulkan bahwa secara parsial sikap berpengaruh signifikan terhadap minat Mahasiswi Universitas Tadulako.

\section{Hasil Pengujian Hipotesis Hasil $\mathrm{X}_{2}$ terhadap $\mathrm{Y}$}

Hipotesis ketiga $\left(\mathrm{H}_{3}\right)$ adalah untuk mengetahui apakah norma subyektif $\left(\mathrm{X}_{2}\right)$ secara parsial berpengaruh signifikan terhadap minat Mahasiswi Universitas Tadulako membeli lipstick merek $L a$ Tulipe. Berdasarkan Tabel di atas menunjukkan bahwa norma subyektif $\left(\mathrm{X}_{2}\right)$ memiliki nilai signifikan sebesar 0.000. Artinya nilai tersebut $<$ dari taraf yang disyaratkan yaitu $\alpha=0.05$, maka dapat disimpulkan bahwa secara parsial norma subyektif berpengaruh signifikan terhadap minat Mahasiswi Universitas Tadulako.

\section{Pembahasan atau Hasil Analisis Secara Serempak}

Berdasarkan hasil pengujian serta analisis yang telah dilakukan pada penelitian ini membuktikan bahwa sikap dan norma subyektifsecara serempak berpengaruh signifikan terhadap minat Mahasiswi Universitas Tadulako membeli lipstik merek La Tulipe. Berdasarkan tabel rekapitulasi regresi linear berganda dapat dilihat pengaruh hasil uji determinasi Adjusted $R$ Square sebesar 0.441. Nilai tersebut dapat diartikan bahwa seluruh dimensi bebas yakni sikap dan norma subyektif mempunyai konstribusi secara bersama-sama sebesar 44,1\% terhadap variabel terikat yaitu terhadapminat Mahasiswi 
Amaliah, D.

Universitas Tadulako membeli lipstik merek La Tulipe. Sedangkan sisanya $(100 \%-44.1 \%=55.9 \%)$, dipengaruhi oleh variabel lain yang tidak diteliti misalnya variabelbehavioral control, dan lain-lain.

Adapun tingkat keeratan hubungan antara variabel bebas yaitu sikap dan norma subyektifterhadap variabel terikat yaituminat Mahasiswi Universitas Tadulako membeli lipstik merek La Tulipe, dapat dilihat dari nilai Multiple R sebesar 0.678 atau 67.8\%. hasil tersebut menunjukkan bahwa secara keseluruhan variabel bebas berhubungan cukup erat terhadap variabel terikat.

Hasil penelitian ini sejalan dengan penelitian sebelumnya yang dilakukan oleh Anggreini (2013), Wiyana \& Japarianto (2014) dan Imelda,dkk (2014) yang menyatakan bahwa sikap dan norma subyektif secara serempak berpengaruh signifikan terhadap minat Konsumen.

\section{Pembahasan atau Hasil Analisis Secara Parsial Sikap $\left(\mathbf{X}_{1}\right)$}

Sikap merupakansalah satu faktor yang dapat mempengaruhi minat seseorang untuk melakukan tindakan pembelian.Sikap adalah sebagai suatu evaluasi yang menyeluruh dan memungkinkan seseorang untuk merespon dengan cara yang menguntungkan atau tidak terhadap terhadap objek yang dinilai.

Dimensi sikap terdiri dari keyakinan terhadap atribut produk dan evaluasi atribut produk. Adapun indikator-indikator yang digunakan untuk mengukur sikap adalah keyakinan akan daya tahan produk, keyakinan akan varian warna produk, keyakinan akan harga produk yang sesuai dengan harga pasaran, keyakinan bahwa produk memiliki kemasan yang menarik, evaluasi akan daya tahan produk, evaluasi akan varian warna produk, evaluasi akan harga produk yang sesuai dengan harga pasaran, evaluasi bahwa produk memiliki kemasan yang menarik.

Penelitian yang dilakukan pada variabel sikap dimana evaluasi akan daya tahan produk merupakan indikator yang dominan dipilih oleh responden. Berdasarkan dasar interpretasi mean dimensi, evaluasi akan daya tahan produk,memiliki pengaruh yang rendah terhadap minat Mahasiswi Universitas Tadulako membeli lipstik merek La Tulipe.

Berdasarkan hasil penelitian ini, indikator-indikator yang digunakan untuk mengukur sikap berpengaruh signifikan terhadap minat Mahasiswi Universitas Tadulako membeli lipstik merek $\mathrm{La}$ Tulipe. Hal ini menunjukkan bahwa sikap dapat mempengaruhi minat Mahasiswi Universitas Tadulako membeli lipstik merek La Tulipe.

Hasil penelitian ini sejalan dengan penelitian sebelumnya yang dilakukan oleh Anggreini (2013) yang membuktikan bahwa sikap secara parsial berpengaruh positif dan signifikan terhadap minat konsumen obyek Agrowisata Pagilaran di Kabupaten Batang, Wiyana \& Japarianto (2014)yang membuktikan bahwa sikap secara parsial berpengaruh positif dan signifikan terhadap perilaku pembelian Harian Kompas di Surabaya dengan minat beli sebagai variabel intervening, dan Imelda, dkk. (2014) yang membuktikan bahwa sikap secara parsialberpengaruh positif dan signifikan terhadap minat konsumen (studi pada pengguna Refill Tinta Printer Dataprint di Banjarmasin).

\section{Norma Subyektif $\left(\mathbf{X}_{2}\right)$}

Norma subyektif merupakan persepsi dari seseorang yang akan mempengaruhi niat seseorang untuk melakukan tindakan, dimana norma subyektif menunjukkan sumber informasi utama yang menjadi acuan konsumen untuk melakukan tindakan pembelian.

Dimensi norma subyektif terdiri dari keyakinan normatif dan motivasi mematuhi. Adapun indikator-indikator yang digunakan untuk mengukur norma subyektif adalah keyakinan akan pendapat orang tua, keyakinan akan pendapat saudara, keyakinan akan pendapat teman, keyakinan akan saran dari sales kosmetik langganan, motivasi untuk memenuhi anjuran orang tua, motivasi untuk mengikuti pendapat saudara, motivasi untuk mengikuti pendapat teman, motivasi untuk mengikuti saran dari sales kosmetik langganan.

Penelitian yang dilakukan pada variabel norma subyektif dimana motivasi untuk mengikuti pendapat teman merupakan indikator yang dominan dipilih oleh responden. Selain itu motivasi untuk mengikuti pendapat saudara juga merupakan indikator yang dapat meningkatkan minat Mahasiswi Universitas Tadulako membeli lipstik merek La Tulipe.

Berdasarkan hasil penelitian ini, indikator-indikator yang digunakan untuk mengukur norma subyektif berpengaruh signifikan terhadap minat Mahasiswi Universitas Tadulako membeli lipstik merek La Tulipe. Hal ini menunjukkan bahwa norma subyektif dapat mempengaruhi minatMahasiswi Universitas Tadulako membeli lipstik merek La Tulipe. 
Hasil penelitian ini sejalan dengan penelitian sebelumnya yang dilakukan oleh Anggreini (2013) yang membuktikan bahwa norma subyektif secara parsial berpengaruh positif dan signifikan terhadap minat konsumen obyek Agrowisata Pagilaran di Kabupaten Batang, Wiyana \& Japarianto (2014) yang membuktikan bahwa norma subyektif secara parsial berpengaruh positif dan signifikan terhadap perilaku pembelian Harian Kompas di Surabaya dengan minat beli sebagai variabel intervening, dan Imelda, dkk. (2014) yang membuktikan bahwa norma subyektif secara parsial berpengaruh positif dan signifikan terhadap minat konsumen (studi pada pengguna Refill Tinta Printer Dataprint di Banjarmasin).

\section{PENUTUP}

\section{Kesimpulan}

Berdasarkan hasil penelitian yang telah dijabarkan, maka diperoleh kesimpulan mengenai pengaruh sikap dan norma subyektif terhadap minat Mahasiswi Universitas Tadulako membeli lipstik merek $L a$ Tulipe.

1. Sikap dan Norma Subyektif secara serempak berpengaruh positif dan signifikan terhadap Minat Mahasiswi Universitas Tadulako Membeli Lipstick Merek La Tulipe.

2. Sikap secara parsial berpengaruh positif dan signifikan terhadap Minat Mahasiswi Universitas Tadulako Membeli Lipstik Merek La Tulipe.

3. Norma Subyektif secara parsial berpengaruh positif dan signifikan terhadap Minat Mahasiswi Universitas Tadulako Membeli Lipstik Merek La Tulipe.

\section{Saran}

Berdasarkan kesimpulan yang telah diuraikan sebelumnya, maka saran-saran yang tepat menyangkut kegunaan penelitian ini dapat diuraikan sebagai berikut:

1. Kepada PT. REMBAKA (La tulipe Cosmetiques) perlu untuk mengikuti trend perubahan sikap konsumen melihat nilai mean pada sikap konsumen bahwa indikator evaluasi akan varian warna produk memiliki nilai mean paling rendah dibanding indikator lainnya yaitu sebesar 1.91, maka PT. Rembaka perlu untuk memperhatikan trend warna masa kini.

2. Kepada PT. REMBAKA (La tulipe Cosmetiques) perlu untuk menigkatkan kemampuan sales dalam meyakinkan konsumen agar berminat melakukan pembelian. Misalnya seperti melakukan training dan evaluasi.

3. Kepada peneliti selanjutnya disarankan untuk memasukkan variabel lain, selain yang digunakan dalam penelitian ini sehingga lebih dapat mengukur sebab-sebab yang mempengaruhi minat beli konsumen memilih lipstick merek La Tulipe,selain itu juga diharapkan untuk menggunakan ukuran sampel yang lebih besar dari jumlah sampel yang digunakan pada penelitian ini sehingga keakuratan hasil penelitian akan lebih terjamin.

\section{REFERENSI}

Anggelina, Jessvita dan Japarianto, Endwin (2014).Analisis Pengaruh Sikap, Subjektive Norm dan Perceived Control Terhadap Purchase Intention Pelanggan SOGO Departemen Store di Tanjung Plaza Surabaya. Jurnal Strategi Pemasaran, Vol. 2, No. 1, (2014) 1-7.

Dewi, Ni Putu Ratih Astarini dan Ardani, I Gusti Agung Ketut Sri (2016). Pengaruh Sikap, Norma Subyektif Terhadap Niat Beli Ulang Produk Fashion Via Online Di Kota Denpasar.E-Jurnal Manajemen Unud, Vol.5, No.1, 2016: 650-677 ISSN: 2302-8912

Ferrinadewi, Erna(2008). Merek \& Psikologi Konsumen (Implikasi Pada Strategi Pemasaran), cetakan pertama. Penerbit Graha Ilmu: Yogyakarta.

Ghozali, Imam (2013). Aplikasi Analisis Multivariat Dengan Program IBM SPSS 21, Edisi7. Universitas Diponegoro: Semarang.

Imelda, Sri. Rofi'i, dan Huwaida, Hikmayanti (2014). Pengaruh Sikap dan Norma Subyektif Terhadap Minat Konsumen (Studi Pada Pengguna Refill Tinta Printer Dataprint di Banjarmasin). Jurnal. Vol XI, No.2 - 2014 ISSN : 1693-4474

Kotler, Philip, dan Gary Armstrong (2008). Prinsip-prinsip Pemasaran. Edisi 12. Jilid 1. Jakarta: Erlangga. 
Amaliah, D.

Kotler, Philip, dan Kevin Lane Keller (2009). Manajemen Pemasaran, Jilid 1 Edisi Ketiga Belas, Terjemahan Bob Sabran, MM. Jakarta: Penerbit Erlangga.

Kotler, Philip, dan Kevin Lane Keller (2009). Manajemen Pemasaran, Jilid 2 Edisi Ketiga Belas, Terjemahan Bob Sabran, MM. Jakarta: Penerbit Erlangga.

Sugiyono (2012). Metode Penelitian Kuantitatif, Kualitatif Dan R\&D. Bandung: Alfabeta.

Sugiyono (2014).Metode Penelitian Bisnis (Pendekatan. Kuantitatif, Kualitatif, dan R\&D), Cetakan Ke-18.Bandung: Alfabeta.

Sugiyono (2015). "Metode Penelitian Kombinasi (Mixed Methods)”. Bandung: Alfabeta

Wiyana, Anna Elrika Chiristin dan Japarianto, Edwin, S.E., M.M. (2014), Pengaruh Sikap Pembaca dan Norma Subyektif Terhadap Perilaku Pembelian Harian Kompas Di Surabaya Dengan Minat Beli Sebagai Variabel Intervening. Jurnal Manajemen Pemasaran Petra, Vol 2, No.1, (2014), Universitas Kristen Petra, Surabaya.

\section{Pustaka Online}

Citra Cendikia Indonesia. www.cci-indonesia.com Diakses 03 Juli 2017 Pukul. 09:10 WITA

Dunia industri Kosmetik http://duniaindustri.com/pasar-industri-kosmetik-diestimasi-tumbuh-9-jadirp-643-triliun/Diakses 02 Juli 2017 Pukul. 10:45 WITA

Majalah MIX Archives - SWA.co.id. http://swa.co.id/tag/majalah-mix. Diakses pada tanggal 2 juli 2017 pukul. 15.20 WITA

Sejarah PT. REMBAKA. www. latulipe - id.com. Diakses 01 Juli 2017 Pukul 09:00 WITA

Top Brand Award. 2016-2018. Top Brand Awards. Online. www.top-brand.com. Diakses 01 Juli 2017 Pukul 09:00 WITA 